\title{
ASME J.P. Den Hartog Award and the ASME N.O. Myklestad Award
}

Published online: 26 May 2010

(C) Springer Science+Business Media B.V. 2010

The Technical Committee on Vibration and Sound (TCVS) of the ASME Design Engineering Division solicits nominations for the 2011 J.P. Den Hartog and N.O. Myklestad awards. These awards, along with an honorarium and plaque, will be presented at the 23rd ASME Biennial Conference on Mechanical Vibration and Noise, as part of the ASME 2011 International Design Engineering Technical Conferences to be held in Washington, D.C., August 28-31, 2011.

The J.P. Den Hartog AWARD, established in 1987, is presented in recognition of lifetime contributions to the teaching and practice of vibration engineering. The recipient will be invited to give the Den Hartog Keynote Lecture at the above conference.

The N.O. MYKLESTAD AWARD, established in 1991, is presented in recognition of a major innovative contribution to vibration engineering.

Nomination packages should include a letter of nomination, 3 to 5 letters of support, the nominee's curriculum vitae, and other supporting documents, if any. All nomination packages must be submitted electronically!

The deadline for the receipt of nomination packages is August 9, 2010.

Submit all nomination packages and inquiries to the TCVS Awards Chair listed below:

Prof. Rob Parker

Distinguished Professor Chair and Associate Dean for Academic Affairs

Univ. of Michigan-Shanghai Jiao Tong Univ. Joint Institute

Shanghai Jiao Tong University

E-mail: rparker@sjtu.edu.cn

\begin{tabular}{lll}
\hline Year & J.P. Den Hartog Award & N.O. Myklestad Award \\
\hline 2009 & E. Dowell & S. Sinha \\
2007 & D.J. Inman & K.W. Wang \\
2005 & C.D. Mote, Jr. & C. Pierre \\
2003 & V. Modi & Y.K. Cheung \\
2001 & Y.K. Lin & V. Melnikov \\
1999 & L. Meirovitch & M. Prohl \\
1997 & A.H. Nayfeh & D. Bently \\
1995 & T.K. Caughey & C.S. Hsu \\
1993 & R.E.D. Bishop & T.C. Huang \\
1991 & S.H. Crandall & N.O. Myklestad \\
1989 & W.T. Thomson & \\
\hline
\end{tabular}

